\title{
Household PV Energy Balance Calculation by Monte Carlo Method
}

\author{
Martin Vins \\ Regional Innovation Centre for Electrical Engineering \\ Faculty of Electrical Engineering, UWB \\ Pilsen, Czechia \\ mvins@fel.zcu.cz
}

\author{
Martin Sirovy \\ Regional Innovation Centre for Electrical Engineering \\ Faculty of Electrical Engineering, UWB \\ Pilsen, Czechia \\ sirovy@fel.zcu.cz
}

\begin{abstract}
Two different approaches for the calculation of the household photovoltaic (PV) installations energy balance are presented and discussed in this paper. The main methodology is based on the Monte Carlo method is proposed and applied to the case study with the effort to increase the annual energy balance calculation accuracy without increasing significantly problem complexity. Results are discussed and compared to the second approach based on direct calculation using only mean values as well as with the real (measured) values of the household energy balance.
\end{abstract}

Keywords-Accuracy Evaluation, Calculation, Comparison, Energy Balance, Household, Mean Values, Monte Carlo Method, Case Study

\section{INTRODUCTION}

Currently, there is an increasing trend in renewable energy sources integration into the energy grid. Due to the constantly improving energy efficiency and decreasing costs of photovoltaic systems are being these installations economically advantageous even without massive subsidies. Very important in this integration are the end customers due to the effort to reduce energy consumption of their households. Electricity production in the place of consumption have clear benefits also in reducing the distribution losses and reducing peak load of the grid in the summer times caused by massive usage of climatization units. Hence, increasing number of installations of these system at the end consumers can positively affect the whole energy grid if the trend keeps continue.

Although the renewables installations at end customers are partly a moral decision, they need to be also economically viable or at least neural. There is not only important a total amount of energy generation but also the concurrency of this generation with local energy consumption and/or accumulation, because the price of energy supply of surpluses in to the grid is usually several-times lower than the price of energy from the grid. Due to this, the most important factor in economical evaluation of these installations is the accurate calculation of the energy balance. This paper will be directly focused on the household PV energy balance calculation. Although there is an increasing trend of complexity of the PV models, there is no clear effect on the increased calculation accuracy, which is described for example in [1] for solar irradiation or in [2] directly for PV cells. But there is also important to say that the very simplified calculation with only mean values can significantly distort results [3].

In this paper will be proposed a simplified methodology using Monte Carlo method (MCM) which should prevent the distortion of the results by use of mean values direct calculation. This methodology will be applied on the specific case study and there will be compared and discussed to the mean values obtained from MCM, mean values from direct calculation and measured real values.

\section{MethodOLOGY}

In this section the methodology of the most important parts of the energy balance calculation will be explained. Due to the intention to maximize accuracy of the calculation, energy balance will be calculated for every hour of the year (time step will be 1 hour).

\section{A. Solar Radiation Energy Estimation}

Method of the calculation of the solar radiation energy typified to the assumed case study (Czechia) is described in [4] and/or [5] in detail. In the case study, it is assumed orientation to the south and inclination $45^{\circ}$.

Basically, it can be said that the instantaneous value of solar radiation $I\left(\mathrm{~kW} / \mathrm{m}^{2}\right)$ can be divided into diffuse $I_{D}$ and direct $I_{P}$ component. The direct component is the clear sky radiation which is absorbed directly. The diffuse component is the radiation which is reflected or absorbed and re-radiated (for example while passing through the clouds). The instantaneous value of the solar radiation can be calculated by the (1).

$$
I=I_{P}+I_{D}
$$

Altitude $H$ is assumed as $303 \mathrm{~m}$, albedo $r$ is assumed as 0.2 and pollution coefficient $Z$ for months of the year is assumed as in city [4] which can be used for verification of calculations described in [4] and/or [5] in detail.

The theoretical (maximal) daily clear sky solar radiation energy $Q_{S \text { day theor }}\left(\mathrm{kWh} / \mathrm{m}^{2}\right)$ is calculated in the (2).

$$
Q_{S \text { day theor }}=\int_{\tau_{r}}^{\tau_{s}} I_{\text {theor }} d d \tau
$$

Where $\tau_{r}(\mathrm{~h})$ is the time of sunrise, $\tau_{s}(\mathrm{~h})$ is the time of sunset and $I_{\text {theor }}\left(\mathrm{kW} / \mathrm{m}^{2}\right)$ is the calculated solar irradiation of the solar day. The calculation of the actual daily solar radiation energy $Q_{S \text { day }}\left(\mathrm{kWh} / \mathrm{m}^{2}\right)$ is expressed by the (3).

$$
\begin{gathered}
Q_{S \text { day }}=\frac{\tau}{\tau_{s}-\tau_{r}} \cdot Q_{S \text { day theor }}+\left(1-\frac{\tau}{\tau_{s}-\tau_{r}}\right) \\
\cdot Q_{D \text { day }}
\end{gathered}
$$

Where $\tau(\mathrm{h})$ is the number of hours of direct sunlight (without clouds) and $Q_{D}$ day $\left(\mathrm{kWh} / \mathrm{m}^{2}\right)$ is the daily diffuse radiation energy which will be the same regardless of cloud cover and is calculated in the (4).

$$
Q_{D \text { day }}=\int_{\tau_{r}}^{\tau_{s}} I_{D} d \tau
$$


The $\tau$ is calculated/estimated from data [6]. To expression of actual hourly solar radiation energy $Q_{S i}\left(\mathrm{kWh} / \mathrm{m}^{2}\right)$ is the $Q_{S \text { day }}$ divided by normal distribution to hours of solar day.

\section{B. Ambient Temperature Estimation}

In the later presented case study, it is assumed that the temperature of the PV panels is the same as ambient temperature due to the fact the better expression of the PV panel's temperature is dependent on a lot of factors which are problematic to estimate and/or there are no available data. This assumption will not significantly complicate the energy balance model and it will increase its accuracy (instead of neglecting the panel's temperature completely).

The hourly ambient temperature calculation $T_{t i}\left({ }^{\circ} \mathrm{C}\right)$ is described in [7] and parametrized to the Czechia according to [8]. There is assumed only time during the day with solar activity (solar day) where the temperature has basically sinusoidal character.

$$
T_{t i}=T_{\text {min }}+A \cdot \sin \left(\left(\tau_{i}-\tau_{r+1}\right) \cdot B \cdot \frac{\pi}{180}\right)
$$

Where $A$ and $B$ are the support temperature constants.

$$
A=T_{\max }-T_{\min } ; B=90 /\left(14.5-\tau_{r+1}\right)
$$

Where $T_{\max }\left({ }^{\circ} \mathrm{C}\right)$ is the maximal daily temperature, $T_{\min }$ $\left({ }^{\circ} \mathrm{C}\right)$ is the minimal daily temperature and $\tau_{i}(\mathrm{~h})$ is the hour of the investigated day. $T_{\max }$ and $T_{\min }$ will be calculated/estimated from data [6].

\section{Household Consumption Estimation}

There are a few ways how to express the hourly household consumption. In this paper, it will be used statistic data from the case study of the installation obtained from [9]. The analysis of the consumption data was made on yearly data set (2020). For easier categorization, the days are divided into four groups:

- Work days October - April,

- Work days May - September,

- Weekends October - April,

- Weekends May - September.

This categorization takes into account the differences in consumption between the heating and non-heating season as well as the differences between presence (weekends) and absence (work days) of residents in the household.

For the parametrization of every group, it was used data sets of 10 to 20 days for generating unique random day sequence of the week. The differences between the groups can be seen in the consumption mean values shown in the Fig. 1 and Fig. 2. Although these are illustrative figures only that show the differences of mean values of consumption in the categorized groups. The simulation itself works with hourly distributions of the consumption in each group which is indicated in the next section.

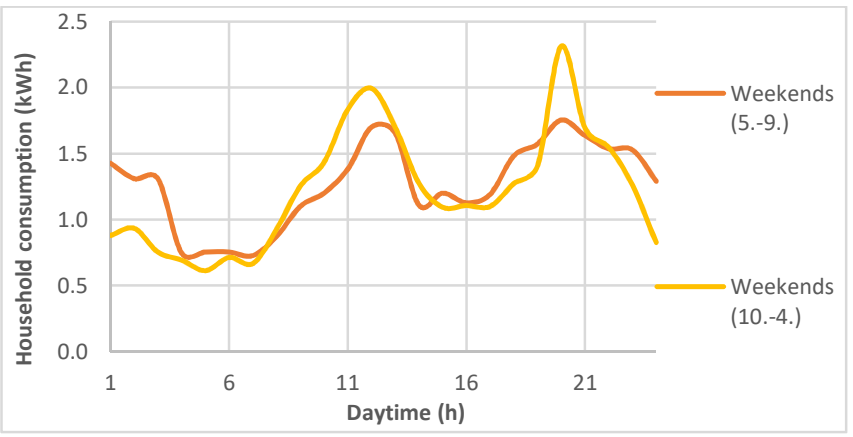

Fig. 1. Mean values of consumption during weekends

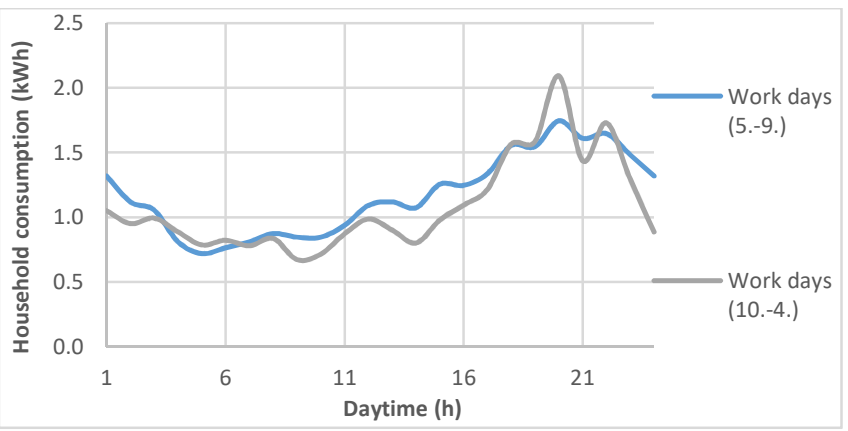

Fig. 2. Mean values of consumption during work days

\section{Battery Energy Storage System Accumulation}

The case study assumes connection to the Battery Energy Storage System (BESS). The expression of State of Charge $(\mathrm{SoC})$ is shown in the (7).

$$
\operatorname{SoC}_{i}=E_{i} \cdot\left(1+\left(\frac{1-e_{B E S S}}{2}\right) \cdot \operatorname{sgn}\left(E_{i}\right)\right)+\operatorname{SoC}_{i-1}
$$

Where $\operatorname{SoC}_{i}(\mathrm{kWh})$ is the hourly State of Charge of the BESS, $e_{B E S S}(-)$ is the efficiency of the BESS charge/discharge cycle and $E_{i}(\mathrm{kWh})$ is the hourly energy balance. In case the $E_{i}$ is positive the BESS is charging, in case the $E_{i}$ is negative the BESS is discharging and in case the $E_{i}$ is equal to zero the $S o C$ remains the same to previous hour.

\section{MONTE CARLO METHOD APPLICATION}

Monte Carlo is a stochastic method which is using random or pseudorandom numbers. The results of the simulation outputs are thus expressed by mean values of a probability density of scenarios outputs.

In this section the specific components of the previously mentioned factors affecting the energy balance will be estimated by MCM and inserted into the previously presented calculations. The distributions of these components will be assumed as normal according to the central limit theorem.

The mean values (direct) calculation uses the same components as MCM but instead of stochastic distributions it will calculate with mean values directly. The result will be apparently one scenario.

The mean values of the monitored parameters will be calculated as weighted averages (MCM), where the weights are the probabilities of the values of the individual scenarios. And as an arithmetic average for the mean values (direct) calculation. 


\section{A. Solar Radiation Energy Estimation}

In this factor, MCM is applied to the $\tau$ estimation from data [6] from years 1978-2018. Example of the distribution for the January $1^{\text {st }}$ is shown in the Fig. 3. The distribution is limited by 0 from left (number of hours of direct sunlight cannot be negative) and by $\tau_{\text {theor }}$ (h) from right (number of hours of the direct sunlight cannot be higher than length of solar day). $\tau_{\text {theor }}$ is calculated in the (8).

$$
\tau_{\text {theor }}=\tau_{s}-\tau_{r}
$$

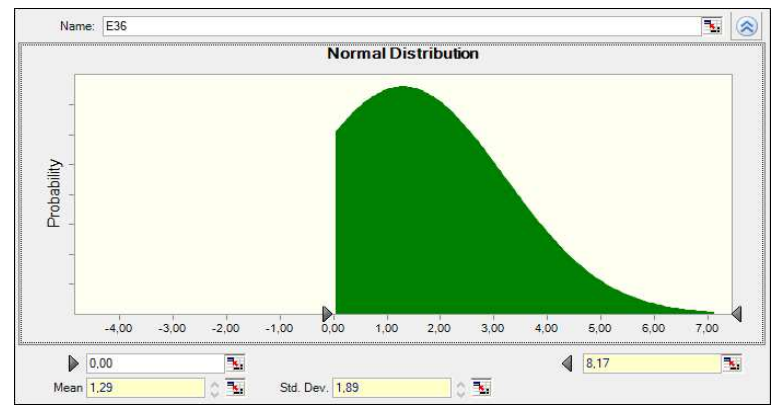

Fig. 3. Expected probability distribution of $\tau$ for January $1^{\text {st }}$

\section{B. Ambient Temperature Estimation}

For an ambient temperature expression is MCM applied to the $T_{\max }$ and $T_{\min }$ estimation from data [6] from years 1978-2018. Example of the distributions for January $1^{\text {st }}$ are shown in the Fig. 4 and the Fig. 5. There is also integrated condition the estimated $T_{\min }$ cannot be higher than the $T_{\max }$ in the same scenario.

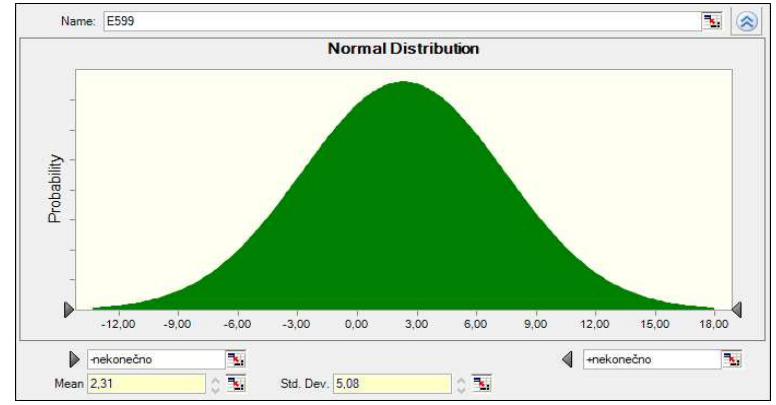

Fig. 4. Expected probability distribution of $T_{\max }$ for January $1^{\text {st }}$

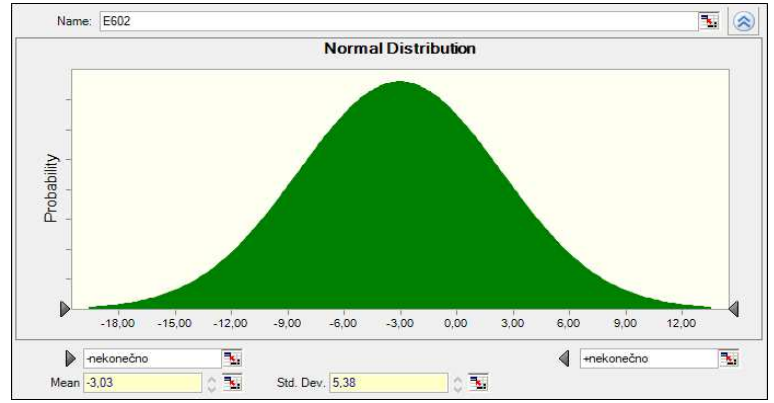

Fig. 5. Expected probability distribution of $T_{\min }$ for January $1^{\text {st }}$

\section{Household Consumption Estimation}

In this case is the hourly household energy consumption $E_{i c}(\mathrm{kWh})$ distribution estimated directly from data [9]. In the Fig. 6, it is shown the expected probability distribution for the 12 - 13 p.m. at workdays May - September.

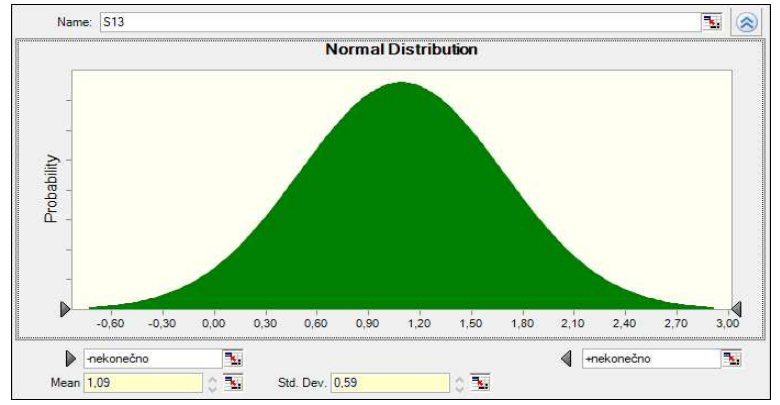

Fig. 6. Expected probability distribution of $E_{i c}$ for the $12-13$ p.m. at workdays May - September

\section{Battery Energy Storage System Accumulation}

State of Charge of the BESS $S o C_{i}$ is then simply calculated for all scenarios as described in (7).

\section{CASE STUdY}

The presented case study is based on the real installation where the estimated energy balance by MCM method is compared to real measured energy balance of the installation obtained from [9]. The selected technical parameters are summarized in the Table I. In this paper, the energy balance calculated for one year of the lifetime of the PV installation (first year) which should be sufficient for the comparison of the methods. In the calculations, it is not assumed aging efficiency decrease. There was calculated 10,000 scenarios by MCM (hardware limitation) in Crystal Ball toolbox of MS Excel.

TABLE I. SELECTED CASE STUDY PARAMETERS

\begin{tabular}{|c|c|}
\hline \multicolumn{2}{|c|}{ Solar panels - Solarwatt ECO 60M; 16 pieces } \\
\hline Rated efficiency $\boldsymbol{e}_{\text {pv rated }}$ & $17.6 \%$ (for $\left.25{ }^{\circ} \mathrm{C}\right)$ \\
\hline Total cells surface $\boldsymbol{S}_{\boldsymbol{c}}$ & $1.47894 \mathrm{~m}^{2}$ \\
\hline Total rated power & $4.560 \mathrm{kWp}$ \\
\hline Temperature/efficiency coefficient $\boldsymbol{c}_{\boldsymbol{T} / \boldsymbol{e}}$ & $-0.42 \% / \mathrm{K}$ \\
\hline Inverter - SONNEN Hybrid 8.13/5 \\
\hline Rated power & $5.5 \mathrm{~kW}$ \\
\hline Rated charging/discharging power & $2.5 \mathrm{~kW}$ \\
\hline Maximal efficiency $\boldsymbol{e}_{\boldsymbol{n}}$ & 0.96 \\
\hline BESS - SONNEN Hybrid $\mathbf{8 . 1 3} / \mathbf{5}$ \\
\hline Capacity & $5 \mathrm{kWh}$ \\
\hline Maximal efficiency $\boldsymbol{e}_{\text {BEss }}$ & 0.98 \\
\hline
\end{tabular}

Due to the unavailability of the efficiency functions will be the efficiencies of the inverter and BESS considered as maximal. The energy balance is followingly calculated by (9) and parameters in Table I.

$$
\begin{gathered}
E_{i}=\left(Q_{S i} \cdot 16 \cdot S_{c}\right) \cdot e_{n} \cdot e_{p v}-E_{i c} \\
\text { If } T_{t i} \leq 25^{\circ} \mathrm{C} \quad e_{p v}=e_{p v \text { rated }} \\
\text { Otherwise } e_{p v}=e_{p v \text { rated }}-\left(T_{t i}-25\right) \cdot c_{T / e}
\end{gathered}
$$

Where $e_{p v}(-)$ is the actual efficiency of the PV panels and $E_{i c}(\mathrm{kWh})$ is the hourly household energy consumption.

\section{RESULTS}

In the Fig. 6, it is shown the histogram of total energy production of the installation calculated by MCM for all scenarios. 


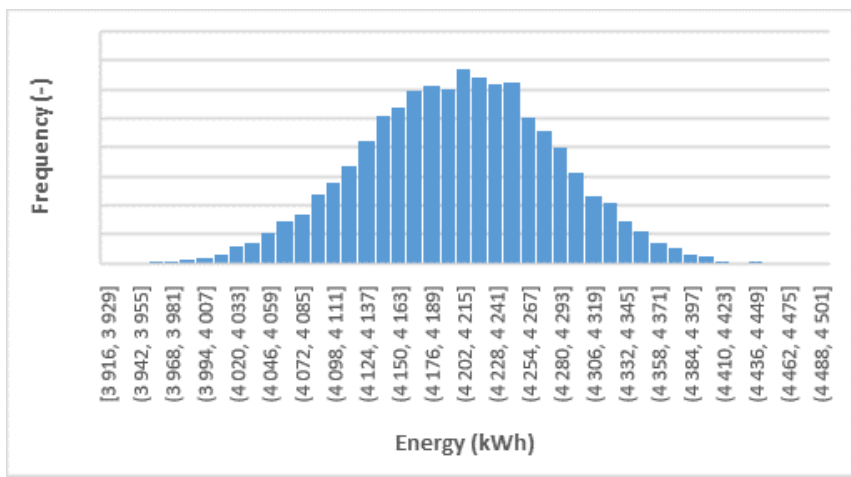

Fig. 7. Expected results of total PV production

In the Fig. 7, it is shown the histogram of gross household energy consumption calculated by MCM for all scenarios.

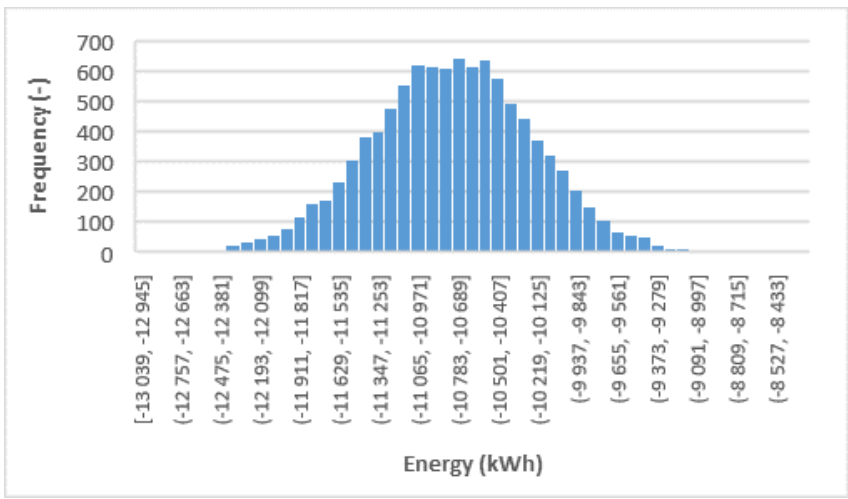

Fig. 8. Expected results of gross household consumption

In the Fig. 8, it is shown the histogram of energy surpluses delivered to the energy grid calculated by MCM for all scenarios.

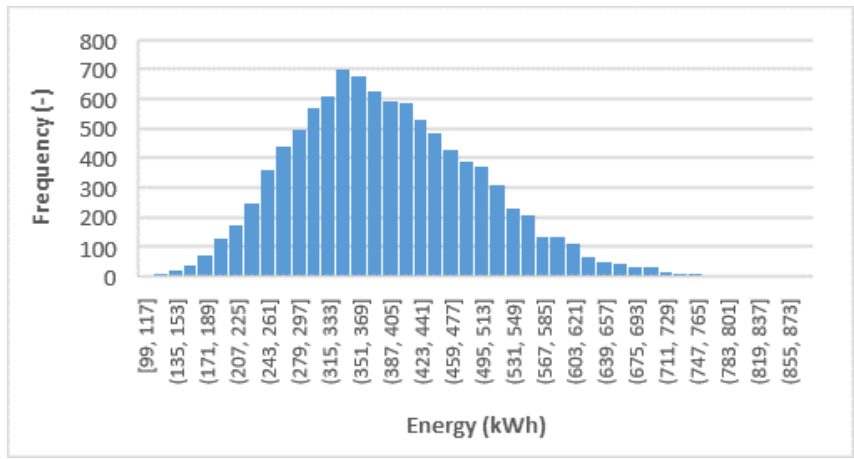

Fig. 9. Expected results of surpluses delivered to grid

In the Table II, there are summarized the results of the calculations by MCM method and mean values method and compared to real measured values.

TABLE II. MEAN CALCULATED AND REAL VALUES

\begin{tabular}{|c|c|c|c|}
\hline Parameter & $\begin{array}{c}\text { Mean values } \\
\text { from MCM }\end{array}$ & $\begin{array}{c}\text { Direct mean } \\
\text { calculation }\end{array}$ & $\begin{array}{c}\text { Real values } \\
\text { (2020) }\end{array}$ \\
\hline$E_{g}$ & $10,778 \mathrm{kWh}$ & $10,121 \mathrm{kWh}$ & $9,372 \mathrm{kWh}$ \\
\hline$E_{n}$ & $6,966 \mathrm{kWh}$ & $6,267 \mathrm{kWh}$ & $5,692 \mathrm{kWh}$ \\
\hline$E_{S}$ & $391 \mathrm{kWh}$ & $127 \mathrm{kWh}$ & $598 \mathrm{kWh}$ \\
\hline $\begin{array}{c}\text { Total } \\
\text { production }\end{array}$ & $4,203 \mathrm{kWh}$ & $3,981 \mathrm{kWh}$ & $4,278 \mathrm{kWh}$ \\
\hline
\end{tabular}

Where $E_{g}(\mathrm{kWh})$ is the yearly household gross energy consumption, $E_{n}(\mathrm{kWh})$ is the yearly household net energy consumption (with energy savings caused by $\mathrm{PV}$ production) and $E_{S}(\mathrm{kWh})$ is the yearly energy surpluses delivered to the energy grid.

\section{DISCUSSION AND CONCLUSION}

As mentioned before, the very complex models of PV installations may not increase accuracy significantly. Nevertheless, the simplified approach using direct calculation with mean values leads to reduction of the accuracy by approximately $5 \%$ as can be seen in the results in the Table II.

The proposed methodology with use of the MCM can improve the PV energy balance accuracy and at the same time it does not have to significantly increase the computational complexity and formulation of the model.

There can be clearly seen that the real values of the total production and mean values from MCM calculation are quite similar. Equivalent case is the yearly energy surpluses delivered to the energy grid where the difference between MCM and real values is higher but in comparison to the direct calculation is the MCM more accurate as well.

The only case, where the direct calculation is more accurate is the household energy consumption (gross or net). This can be caused by simplified categorization to the groups of the consumption days. Due to this fact the distributions can be affected by random phenomena which are not included in selected sample days (for example vacations of the residents) or the fact that the consumption during the year is more variable. To eliminate this problem, we suggest using more precise categorization (like workdays and weekend days during the months). This may not eliminate the effect of all random phenomena but it should increase energy consumption accuracy calculation in general.

\section{ACKNOWLEDGMENT}

This paper is supported by the student research project SGS-2021-021.

\section{REFERENCES}

[1] Perpiñan, O., et al. "On the complexity of radiation models for PV energy production calculation." Solar Energy, vol. 82, no. 2, 2008, pp. 125-131., doi:10.1016/j.solener.2007.06.007.

[2] Manuel Godinho Rodrigues, Eduardo, et al. "Simulation and Comparison of Mathematical Models of PV Cells with Growing Levels of Complexity." Energies, vol. 11, no. 11, 2018, p. 2902., doi:10.3390/en11112902.

[3] Martin, N., and J.M. Ruiz. "Calculation of the PV Modules Angular Losses under Field Conditions by Means of an Analytical Model." Fuel and Energy Abstracts, vol. 43, no. 4, 2002, p. 269., doi:10.1016/s01406701(02)86350-0.

[4] Cihelka Jaromír, and Wagnerová Denisa. Solární tepelná technika. Tomáš Malina, 1994.

[5] Škorpík, Jiří. "Sluneční záření jako zdroj energie.” Transformační Technologie, [cit. 11. 16. 2020], www.transformacnitechnologie.cz/02.html\#1214.

[6] Portál ČHMÚ : Historická data : Počasí : Denní data : Data ze stanic sitě RBCN, [cit. 12. 10. 2020], www.chmi.cz/historickadata/pocasi/denni-data/data-ze-stanic-site-RBCN\#.

[7] Linvill, Dale E. "Calculating chilling hours and chill units from daily maximum and minimum temperature observations." HortScience, vol. 25, no. 1, 1990, pp. 14-16., doi:10.21273/hortsci.25.1.14.

[8] Svoboda, A., and T. Litschmann. Metodika výpočtu sum hodinových teplot vzduchu $z$ dennich teplotnich extrémů a jejich využiti $v$ ovocnictví, [cit. 15. 12. 2020] www.amet.cz/denchod.html.

[9] Sonnen Customer Portal, [cit. 1. 10. 2021], my.sonnen.de/demo/analysis. 